\title{
Lactation Curve, Milk Production of Pelibuey Ewes and Preweaning Growth Rate of the Lambs
}

\author{
Rodríguez-Álvarez, Hugo A. ${ }^{1}$; Hinojosa-Cuéllar, José A. ${ }^{2}$; González-Garduño, Roberto ${ }^{3}$; \\ Gallegos-Sánchez, Jaime ${ }^{1}$; Rubio-Rubio, Moisés ${ }^{4}$; Aranda-Ibáñez, Emilio M. ${ }^{5}$; \\ Oliva-Hernández, Jorge ${ }^{6}$; Torres-Hernández, Glafiro ${ }^{1^{*}}$ \\ ${ }^{1}$ Colegio de Postgraduados Campus Montecillo. Montecillo, Texcoco, Estado de México, México. C.P. 56230. \\ ${ }^{2}$ Universidad Popular de la Chontalpa. Cárdenas, Tabasco, México. C.P. 86530. \\ ${ }^{3}$ Unidad Regional Universitaria Sursureste, Universidad Autónoma Chapingo, Teapa-Vicente Guerrero, \\ Teapa, Tabasco, México. C.P. 86800. \\ ${ }^{4}$ Colegio Superior Agropecuario del Estado de Guerrero, Iguala, Guerrero, México. C.P. 40000. \\ ${ }^{5}$ Colegio de Postgraduados-Campus Tabasco, Cárdenas, Tabasco, México. C.P. 86500 \\ ${ }^{6}$ Instituto Nacional de Investigaciones Forestales, Agrícolas y Pecuarias. Campo Experimental Huimanguillo. \\ Huimanguillo, Tabasco, México. C.P. 86400. \\ * Corresponding author: glatohe@colpos.mx
}

Citation: Rodríguez-Álvarez, Hugo A., Hinojosa-Cuéllar, José A., GonzálezGarduño, Roberto, Gallegos-Sánchez, Jaime, Rubio-Rubio, Moisés, ArandaIbáñez, Emilio M., Oliva-Hernández, Jorge, \& Torres-Hernández, Glafiro. (2021). Lactation Curve, Milk Production of Pelibuey Ewes and Preweaning Growth Rate of the Lambs. Agro Productividad, 14(\#). https://doi.org/10.32854/agrop. v14i6.1850

Editor in Chief: Dr. Jorge Cadena Iñiguez

Estimated publication date: July 2021

This work is licensed under a Creative Commons Attribution-NonCommercial 4.0 International license
ABSTRACT

Objective: To estimate the lactation curve and milk production of Pelibuey ewes and their relationship with preweaning growth rate of the lambs.

Design/Methodology/Approach: Forty-five Pelibuey ewes were milked during 70 days in Montecillo, Mexico, in 2018, to estimate the daily and total milk production. The lactation curve was fitted with the incomplete gamma function. In addition, the effects of type of birth and ewe weight at milking on milk production were analyzed, and correlations were calculated between ewe milk production and growth rate of the lambs, per week and for the entire lactation.

Results: A "typical" lactation curve was found, average ewe milk production for the whole lactation, weighted for the number of lambs suckling, was $131 \pm 8 \mathrm{~L}$, with $444 \pm 24 \mathrm{~g} \mathrm{~d}^{-1}$. Ewe weight at milking had an effect $(p<0.01)$ on milk production. Positive correlations were found $(p<0.05)$ between ewe milk production and preweaning growth rate of the lambs.

Study Limitations/Implications: There is a strong dependency of the lambs on the milk production of the Pelibuey ewe, a factor of great relevance so that lambs can gain body weight and survive during lactation. Findings/Conclusions: Pelibuey ewes produce less milk than dairy ewes. Therefore, lambs should be weaned at a maximum of 10 weeks of lactation.

Keywords: maternal ability, live weight, lamb survival.

\section{INTRODUCTION}

Sheep production in Mexico is an activity that has attained great advances in the productive and commercial aspect because mutton represents an important option for the diet, product that is consumed primarily as a traditional dish known as "barbacoa". The predominant hair breeds in Mexico are Pelibuey and Blackbelly (Hinojosa-Cuéllar et al., 2012). Of these, the most frequently used in Mexico in grazing and mixed systems is Pelibuey, primarily due to its adaptation to various agro-climate environments, which currently is a factor of great consideration because of the climate changes affecting the animals (Núñez-Domínguez et al., 2016; Tsartsianidou et al., 2021), and also due to its characteristics of prolificacy and rusticity (Ramón-Ugalde and SanginésGarcía, 2002) and resistance to gastrointestinal nematodes (Zaragoza-Vera et al., 2019). In sheep production systems for meat in grazing without dietary supplementation, the 
production and quality of the ewe milk is vital for the lambs during the first weeks of life (Peniche et al., 2015), so a strong relationship has been found between the growth rate and the survival of the lambs with milk production (MP) of the ewe during lactation (Afolayan et al., 2009; Naik et al., 2016).

In hair sheep, information about MP and associated characteristics is very limited, for example knowledge about the lactation curve (Adewumi and Olorunnisomo, 2009; Güngör and Atasoy, 2020), as well as the relationship between the ewe's MP and the lambs' daily weight gain (LWG) during the lactation. Understanding the lactation curve is important because it allows the sheep producer to make decisions about animal management, such as monitoring the diet, the health state, discarding animal, which are factors that impact the economy of milk production (Takma et al., 2009; Tekel et al., 2019). In Mexico there are studies carried out in hair sheep (Peniche et al., 2015; Chay-Canul et al., 2019) where the MP was evaluated; however, in these studies the relationship between MP and the lamb's growth rate (LGR) was not determined, and in hair lamb production systems for supply it is important to understand the milk production of the ewes. Therefore, the objectives of this study were: 1) to fit the lactation curve of Pelibuey ewes, 2) to estimate the total and daily milk production of the ewes, 3) to evaluate the effects of the number of lambs suckling and the ewe weight at milking on the MP, and 4) to calculate the correlations between the MP and the LGR, per week and total.

\section{MATERIALS AND METHODS}

\section{Location, animals and management}

This study was performed in the Sheep and Goat Reproduction Laboratory belonging to Colegio de Postgraduados, Campus Montecillo, located in MontecilloTexcoco, Estado de México. This place is located in coordinates $19^{\circ} 29^{\prime}$ Latitude North and $98^{\circ} 53^{\prime}$ Longitude West, at 2250 masl. The climate is classified as temperate subhumid with summer rains (García, 2004).

Forty-five second birth Pelibuey ewes were used with an initial average weight of $49.1 \pm 13.6 \mathrm{~kg}$, of which 27 were of single birth and 18 of double birth. The ewes began lambing on May 17, 2018. Since lambing, the ewes were fed with a commercial diet (Table 1 ) that had $14 \%$ raw protein and $2.96 \mathrm{Mcal} \mathrm{kg}^{-1}$ digestible energy.

Likewise, they always had access to clean and fresh water. The daily serving was divided into equal parts in the morning and the afternoon, while alfalfa was offered only in the mornings. The health program of the ewes included elimination of gastrointestinal nematodes at the beginning of the study, and sodium Levamisol (Prolevan ${ }^{\circledR}$ ) was used in a dose of $1 \mathrm{~mL}$ for every $20 \mathrm{~kg}$ of live weight; for vaccination against pneumonic pasteurellosis, symptomatic carbon, malign edema, and enterotoxemia, the Vaccine:bobac 8 was used in the last third of gestation in a dose of $2.5 \mathrm{~mL}$ per ewe; in addition, $2 \mathrm{~mL}$ of the ADE vitamin complex per ewe were used. The ewes started to be milked manually in the mornings (08:00 h) on day five postlambing to allow the consumption of colostrum by the lambs, and since then every seven days for 10 weeks, with a total of 70 days in lactation. Therefore, the first record 
of MP was since day 5 post-lambing. In this study three milking sessions were carried out every week at intervals of $2 \mathrm{~h}$ each (08:00 to 14:00 h). To measure the MP the double weighting method (DWM) of the lamb was used (Benson et al., 1999), which consists in weighing the lambs before and after suckling to have an estimation of milk produced by the ewe in every session, and later removing through manual milking the residual milk contained in the udder. This measurement was carried out in each session of $6 \mathrm{~h}$ and repeated every week during the 10 total weeks of the trial. In the day prior to the first measurement, the lambs were put away in a pen at $18.00 \mathrm{~h}$ to separate them from their mothers, although between mothers and lambs sight and smell were possible, but not suckling. The ewes were put away in a separate pen, without considering the type of birth. On the next day, start of the first session, the lambs were allowed to exit their pen to seek their mothers and once they located the ewe their live weight was taken, after which they were allowed to suckle until emptying the udder. Once the lamb was no longer suckling it was weighed again, to therefore have an estimator of the ewe's milk production. This procedure was repeated in the next two sessions and throughout the lactation. The MP of the three sessions was added and the amount of residual milk that corresponded was added to this, thus obtaining an estimator of the MP produced in $6 \mathrm{~h}$. The resulting value was multiplied by four, to have an estimator of the MP produced in $24 \mathrm{~h}$, under the assumption that the amount of milk produced was constant during the day (Cardellino and Benson, 2002). The assumption was also made that this MP measured every week represents the average daily milk production for the week that it was measured (Al Jassim et al., 1999). Milk production of the ewe per week was recorded, and for the whole lactation period.

\section{Statistical procedure}

To fit the lactation curve, the incomplete gamma function or Wood's model (Wood, 1967) was used, because its three parameters are linked to the biology of the lactation curve (Portolano et al., 1996), and because it has had good results in milk production studies in ewes (Ángeles Hernández et al., 2014; Nava-García et al., 2019). Fitting the lactation curve was done based on the average of the individual lactation curves, both for the group of ewes with one lamb and with those that had two lambs. The model is: $y_{t}=a t^{b} e^{-c t}$, where: $y_{t}$ is the milk production in day $t$, e is the base of the natural logarithm, $a, b$ and $c$ are parameters of the curve, where a represents the milk production at the beginning of the lactation, while $b$ and $c$ represent the limit decline of the curve before and after the peak of lactation, respectively. With the purpose of analyzing the model linearly, a logarithmic transformation was carried out, and the model resulted as follows: $\log y_{t}=\log a+b \log t-c n$, after which the parameters $a, b$, and $c$ were estimated through multiple linear regression. After obtaining parameters $a, b, c$, according to Nezamidoust et al. (2013) and taking the average of all the ewes, the following were obtained: the peak of lactation (PLA) as: $Y_{\max }=a(b / c) b e-b$, the time until the peak of lactation (TPLA) as: b/c, and the persistence as: $(S)=-(b+1) \ln \mathrm{c}$. Only the value of $Y_{\max }$ was obtained with the NLIN procedure of the statistical package SAS (2004). 
Then, an analysis of variance was performed using the GLM procedure of SAS (2004) to evaluate the effects that the independent variables can have, such as type of birth of the offspring (single and double) and ewe weight at milking (as covariable) on the dependent variable total MP. Finally, the correlations between MP of the ewe and LGR were calculated, per week and total. It should be clarified that the LGR was used because the weight of the lambs before and after suckling represented an estimator of the ewe's milk production, which was an objective of the study, not the weight gains of the lambs, so they were not weighed for this purpose.

\section{RESULTS AND DISCUSSION}

The lactation curves of ewes with one and two lambs are shown in Figure 1. The lactation peaks (maximum milk production) in ewes with one and two lambs were found in the second and third week of lactation, respectively.

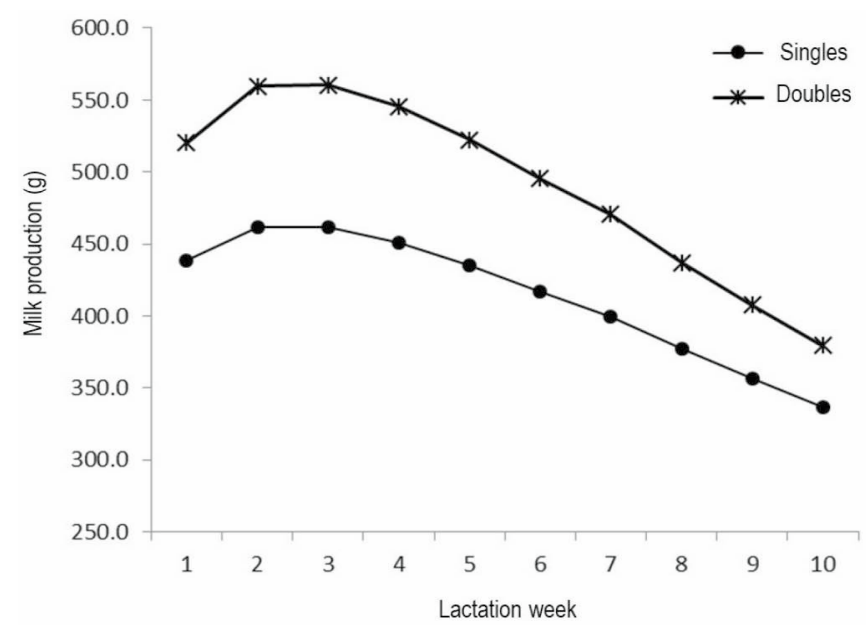

Figure 1. Milk production lactation curve of Pelibuey ewes according to number of lambs suckling.

Table 2 presents the estimated total milk productions for ewes with one and two lambs.

Table 2. Total milk production of Pelibuey ewes (mean \pm s.e.), nursing one $(n=27)$ or two $(\mathrm{n}=18)$ lambs, total lactation milk production, and daily mean production.

\begin{tabular}{l|c|c} 
& One lamb & Two lambs \\
\hline Total milk production (liters) & $122 \pm 1.8 \mathrm{a}$ & $144 \pm 2.2 \mathrm{a}$ \\
\hline Total milk production/ewe (liters)* & \multicolumn{2}{|c}{$131 \pm 8$} \\
\hline Mean daily milk production/ewe (g)** & \multicolumn{2}{|c}{$444 \pm 24$} \\
\hline *: weighted mean for the number of lambs suckling during the entire lactation (70 days). \\
**: average for the entire lactation. a: no significant differences ( $\mathrm{p}>0.05$ ).
\end{tabular}

Table 3 shows the estimators ( $\mathrm{a}, \mathrm{b}, \mathrm{c}$ ) of the parameters obtained from the lactation curve for ewes with one and two lambs. 
Table 3. Parameters ( \pm standard error) of the milk production lactation curve obtained from the Wood model, according to lamb birth type (BT).

\begin{tabular}{|c|c|c|c|}
\hline Parameter & $\mathbf{a}$ & b & c \\
\hline \multicolumn{4}{|l|}{ BT: } \\
\hline Single & $0.44 \pm 0.072$ & $0.186 \pm 0.021$ & $0.010 \pm 0.001$ \\
\hline Double & $0.53 \pm 0.070$ & $0.210 \pm 0.022$ & $0.015 \pm 0.001$ \\
\hline
\end{tabular}

a: milk production at the beginning of lactation, $\mathrm{b}$ : limit decline of the curve before the peak of lactation, c: limit decline of the curve after the peak of lactation.

For the entire lactation, the average production per ewe, weighed by the number of lambs suckling, was $131 \pm 8 \mathrm{~L}$ with an average of $444 \pm 24 \mathrm{~g} \mathrm{~d}^{-1}$ (Table 2).

For the whole lactation period, it was found that the ewes that were suckling two lambs produced a similar amount of milk than that produced by ewes that suckled only one lamb ( $\mathrm{p}>0.05$, Table 2).

Table 4 shows the PLA values according to the type of birth of the lamb (single, double), of the TPLA, and those of persistence; these did not show significant differences between one another $(p>0.05)$.

Table 4. Lactation peak (LP), time at lactation peak (TLP) and persistency (S), according to ewes of single $(n=27)$ and double $(n=18)$ birth type.

\begin{tabular}{l|c|c|c}
\multicolumn{1}{c}{ Variable } & LP & TLP & S \\
\hline Birth type: & \multicolumn{3}{|l}{} \\
\hline Single & $409.5 \mathrm{a}$ & $14.2 \mathrm{a}$ & $-5.09 \mathrm{a}$ \\
\hline Double & $463.4 \mathrm{a}$ & $16.9 \mathrm{a}$ & $-5.35 \mathrm{a}$ \\
\hline
\end{tabular}

a: no significant differences ( $p>0.05)$.

The weight of the ewe at milking (as covariable) had a significant influence $(\mathrm{p}<0.01)$ on the MP; a regression coefficient of $b_{y / x}=0.026 \mathrm{~kg}$ was found, value that indicates that for each $\mathrm{kg}$ of live weight gain of the ewe at the time of milking, the MP increased in $26 \mathrm{~g}$.

Finally, Table 5 shows the correlation coefficients between MP and LGR, per week and total.

It can be observed that the correlations were significant, except in the cases of the single birth (week 3), double birth (week 6), and in both types of birth (week 10), this being the last week that corresponds to the date when the ewes were close to drying up. It can also be seen that the magnitude of the correlations shows a tendency to decrease with time, this being more evident in the ewes rearing two lambs.

The average and adjusted lactation curves, both for ewes with one lamb and with those with two lambs, correspond to a "typical" curve, which is characterized by having a gradual increase at the beginning of the lactation until reaching the peak of lactation, followed by a gradual decline until the end of the lactation that corresponds to the type of curve that has been found in other groups of sheep, as in Cuban Pelibuey (Pérez Corría et al., 2017) and East Friesian (Ángeles Hernández et al., 2018). The time until the peak of lactation in this study agrees with the results obtained by Benson 
et al. (1999) in Suffolk ewes using also the DWM, and with those by Cardellino and Benson (2002) in ewes milked through mechanical milking. However, it differs from the results by Peniche et al. (2015), Allah et al. (2011), and Peralta-Lailson et al. (2005) in terms of the dates of time until the peak of lactation, since in these studies the dates were weeks seven, five and one, respectively. These differences regarding the of type of lactation and date of the time until the peak of lactation is attributed mainly to the effects of the genotype of the ewe and management practices, as found by Aboul-Naga et al. (1981) when comparing three sub-tropical non-dairy sheep breeds. Peralta-Lailson et al. (2005) in Mexico's Chiapas sheep of the black, white, and brown varieties, concluded that another factor that can influence the lactation curve is the selection effect.

Table 5. Phenotypic correlations between ewe milk production and growth rate of lambs (per week and total), according to lamb birth type (BT).

\begin{tabular}{|c|c|c|}
\hline \multicolumn{3}{|c|}{ BT } \\
\hline Week & Single & Double \\
\hline 1 & $0.68^{* *}$ & $0.73^{* *}$ \\
\hline 2 & $0.53^{* *}$ & $0.61^{* *}$ \\
\hline 3 & $0.32^{\mathrm{ns}}$ & $0.58^{* *}$ \\
\hline 4 & $0.67 * *$ & $0.62^{* *}$ \\
\hline 5 & $0.58^{* *}$ & $0.47^{* *}$ \\
\hline 6 & $0.50^{* \star}$ & $0.31^{\mathrm{ns}}$ \\
\hline 7 & $0.47^{* \star}$ & $0.52^{* *}$ \\
\hline 8 & $0.54^{* *}$ & $0.58^{* *}$ \\
\hline 9 & $0.43^{* *}$ & $0.48^{* *}$ \\
\hline 10 & $0.32^{\mathrm{ns}}$ & $0.28^{\mathrm{ns}}$ \\
\hline Total & $0.68^{* *}$ & $0.75^{\star *}$ \\
\hline
\end{tabular}

*: $\left.p<0.05,{ }^{* *}: p<0.01\right),{ }^{n s}$ : non-significant $(p>0.05)$.

Afolayan et al. (2002) also found that the parameters $a, b$, and $c$ were higher in ewes with two lambs, which suggests that the number of lambs suckled by the ewe has an important influence on the MP, which has been found before in other sheep breeds (Snowder and Glimp, 1991). On the other hand, Afolayan et al. (2002) mentioned that the parameters $b$ and $c$ are the ones responsible for shaping the lactation curve. In Mexico's Chiapas sheep, Peralta-Lailson et al. (2005) used Wood's model, and they found that Creole Chiapas ewes of the white and brown varieties had atypical lactation curves, which is attributed to the values of parameters $b$ and $c$. Some estimators of the parameters of Wood's model that have been estimated in dairy ewes are $a=0.979$, $b=0.071, c=0.009$ (Ángeles-Hernández et al., 2013), $a=1,333, b=0.3, c=0.092$ (Miguel et al., 2016); in these studies, the magnitude of parameter a standout, which represents milk production at the beginning of the lactation, indicating specialized breeds in milk production. 
Estimators of daily averages of MP that have been obtained in hair ewes are: 131 g in Mexico Pelibuey ewes (Castellanos Ruelas and Valencia-Zarazúa, 1982); 1.43 and $1.77 \mathrm{~kg}$ in Mexico Pelibuey and Katahdin ewes, respectively (Chay-Canul et al., 2019); 123 and $173 \mathrm{~g}$ in Blackbelly and St. Croix ewes, respectively (Godfrey et al., 1997); 1,200 $\mathrm{g}$ in Martinik ewes (Ortega-Jiménez et al., 2005); 1,400 g in Santa Inés ewes (Araujo et al., 2008). According to Godfrey et al. (1997) and Robles-Jiménez et al. (2020), the differences in daily milk production can be attributed mainly to the genotype of the ewe and management practices, although Aboul-Naga et al. (1981) and Peralta-Lailson et al. (2005) also include the selection effect.

Most studies indicate that ewes with two lambs produce more milk than those with only one (Cardellino and Benson, 2002; Morgan et al., 2006), and it has been mentioned that the ewes that carry more than one offspring have a higher concentration of serum progesterone and a high volume of the placenta, producing an increase in placental lactogen, thus stimulating the development of the mammary gland during gestation and before lambing, which in turn provokes an increase in MP (Ochoa-Cordero et al., 2007; Adegoke et al., 2015). Other factors, such as the histo-morphological characteristics of the udder can also affect the MP in ewes (Murawski et al., 2019). The lack of differences in MP between ewes with one lamb and ewes with two lambs could be attributed to the size of the sample used in this study.

Heavier ewes generally produce more milk than those of lower body weight (van der Linden et al., 2009) and an influence has been found ( $<<0.01)$ of the ewe weight at the time of birth on the MP (Ángeles Hernández et al., 2018), and in genetic improvement programs the body weight of the ewe is used as a selection criterion to increase milk production (Mavrogenis and Papachristoforou, 2000). In the literature, no studies were found where the effect of the ewe weight at the time of milking on the MP has been analyzed. In this study it was decided to measure the ewe weight at milking during the 10 weeks due precisely to its proximity to the moment of milking; however, an inconvenience of this procedure could be the stress and management to which ewes are subjected, whose effect was not quantified in this study.

Godfrey et al. (1997) found a correlation of $r=0.37(p<0.0001)$ in St. Croix ewes between pre-weaning LWG of the lambs and MP of the ewe measured by the oxytocin method; however, in Blackbelly ewes from the same study the correlation $(r=0.17)$ was not significant $(\mathrm{p}>0.10)$. Using the lamb's DWM to measure MP in wool ewes, Snowder and Glimp (1991) and Benson et al. (1999) mention positive correlations ( $\mathrm{p}<0.05)$ between MP of the mother and pre-weaning LWG of the lambs. In the study by Benson et al. (1999), the correlation between pre-weaning LWG of the lambs and MP of the mother throughout the lactation (63 days) was $r=0.60(p<0.03)$, indicating in this study the strong dependence of the lambs on the mother's milk to gain weight and survive, since the lambs did not have access to solid food during the entire lactation. Snowder and Glimp (1991) mentioned in their study that the decreasing value of the correlations as the lactation advanced indicates that in lambs the dependency on milk for their growth decreases. 


\section{CONCLUSIONS}

Pelibuey ewes show a typical lactation curve, characterized by a gradual increase in milk production until reaching a peak, followed by a gradual decrease until the end of the lactation. Milk production during the entire lactation was $131 \pm 8 \mathrm{~L}$, with a daily average of $444 \pm 24 \mathrm{~g}$. There were no differences $(\mathrm{p}>0.05)$ in milk production between ewes suckling one or two lambs in the whole lactation. The weight of the ewe at milking (as covariable) had an effect ( $\mathrm{p}<0.01$ ) on milk production; for every kg of the ewe's weight increase at milking, the milk production increased in $26 \mathrm{~g}$. For the entire lactation, positive correlations were obtained $(\mathrm{p}<0.01)$ between total milk production and growth rate of the lambs.

\section{AKNOWLEDGEMENTS}

The authors thank the support from students and workers who collaborated in the general management of the animals and data collection during the field work. The first author received a scholarship from CONACYT for Master's in Science studies.

\section{REFERENCES}

Aboul-Naga, A.M., El-Shobokshy, A.S., \& Moustafa, M.A. (1981). Milk production from subtropical non-dairy sheep. 2. Method of measuring. Journal of Agricultural Science, 97(2), 303-308.

Adegoke, E.O., Ezekwe, A.G., \& Agaviezor, O.B. (2015). Effect of parity and birth type on udder characteristics and milk yield of West African Dwarf sheep. International Journal of Scientific \& Technology Research, 4(10), 27-32.

Adewumi, O.O., \& Olorunnisomo, O.A. (2009). Milk yield and milk composition of West African dwarf, Yankasa and crossbred sheep in southwest of Nigeria. Livestock Research for Rural Development, 21(3), 1-7.

Afolayan, R.A., Abubakar, B.Y., Osinowo, O.A., \& Dim, N.I. (2002). Lactation and function of curve parameters in Yankasa sheep. Asian-Australasian Journal of Animal Sciences, 15(6), 890-894.

Afolayan, R.A., Fogarty, N.M., Morgan, J.E., Gaunt, G.M., Cummins, L.J., \& Gilmour A.R. (2009). Preliminary genetic correlations of milk production and milk composition with reproduction, growth, wool traits and worm resistance in crossbred ewes. Small Ruminant Research, 82(1), 27-33.

Allah, M.A., Abass, S.F., \& Allam, F.M. (2011). Factors affecting the milk yield and composition of Rahmani and Chios sheep. International Journal of Livestock Production, 2(3), 24-30.

Al Jassim, R.A.M., Aziz, D.I., Zorah, K., \& Black, J.L. (1999). Effect of concentrate feeding on milk yield and body-weight change of Awassi ewes and the growth of their lambs. Animal Science, 69(2), 441-446.

Ángeles-Hernández, J.C., Albarrán-Portillo, B., Gómez González, A.V., Pescador Salas, N., \& González-Ronquillo, M. (2013). Comparison of mathematical models applied to F1 dairy sheep lactations in organic farm and environmental factors affecting lactation curve parameter. Asian-Australasian Journal of Animal Sciences, 26(8), 1119-1126.

Ángeles Hernández, J.C., Castelán Ortega, O., Albarrán Portillo, B., Montaldo, H.H., \& González Ronquillo, M. (2014). Application of the wood model to analyse lactation curves of organic dairy sheep farming. Animal Production Science, 54(10), 1609-1614.

Ángeles Hernández, J.C., Radic Schilling, S., Vera Arias, M.A., Echeverría Pérez, R.A., Castelán-Ortega, O.A., Ramírez Pérez, A.H., \& González Ronquillo, M. (2018). Effect of live weight pre- and post-lambing on milk production of East Friesian sheep. Italian Journal of Animal Science, 17(1), 184-194.

Araujo, R.C., Pires, A.V., Susin, I., Mendes, C.Q., Rodrigues, G.H., Packer, I.U., \& Eastridge, M.L. (2008). Milk yield, milk composition, eating behavior, and lamb performance of ewes fed diets containing soybean hulls replacing coastcross (Cynodon species) hay. Journal of Animal Science, 86(12), 3511-3521. 
Benson, M.E., Henry, M.J., \& Cardellino, R.A. (1999). Comparison of weigh-suckle-weigh and machine milking for measuring ewe milk production. Journal of Animal Science, 77(9), 2330-2335.

Cardellino, R.A., \& Benson, M.E. (2002). Lactation curves of commercial ewes rearing lambs. Journal of Animal Science, 80(1), 2327.

Castellanos Ruelas, A., \& Valencia Zarazúa, M. (1982). Estudio cuantitativo y cualitativo de la producción láctea de la oveja Pelibuey. Producción Animal Tropical, 7(3), 245-253.

Chay-Canul, A.J., Aguilar-Urquizo, E., Parra-Bracamonte, G.M., Piñeiro-Vázquez, A.T., Sanginés-García, J.R., Magaña-Monforte, J.G., García-Herrera, R.A., \& López-Villalobos, N. (2019). Ewe and lamb pre-weaning performance of Pelibuey and Katahdin hair sheep breeds under humid tropical conditions. Italian Journal of Animal Science, 18(1), 850-857.

García, E. (2004). Modificaciones al Sistema de Clasificación Climática de Köppen. Quinta edición. UNAM: México.

Godfrey, R.W., Gray, M.L., \& Collins, J.R. (1997). Lamb growth and milk production of hair and wool sheep in a semi-arid tropical environment. Small Ruminant Research, 24(2), 77-83.

Güngör, I., \& Atasoy, F. (2020). Use of multiple regression modeling for the evaluation of lactation characteristics of Awassi sheep. Livestock Studies, 60(2), 46-53.

Hinojosa-Cuéllar, J.A., Oliva-Hernández, J., Torres-Hernández, G., Segura-Correa, J.C., Aranda-Ibáñez, E.M., \& GonzálezCamacho, J.M. (2012). Factors that affect pre-weaning growth of Pelibuey lambs in the humid tropics of México. Universidad y Ciencia, 28(2), 163-171.

Mavrogenis, A.P., \& Papachristoforou, C. (2000). Genetic and phenotypic relationships between milk production and body weight in Chios sheep and Damascus goats. Livestock Production Science, 67(1-2), 81-87.

Miguel, J.A., Calvo, J.L., Ciria, J., \& Asenjo, B. (2016). Caracterización y modelización de las cinco primeras semanas de lactación en ovejas de parto simple de raza Ojalada para la producción de lechazo. Información Técnica Económica Agraria, 112(1), 34-44.

Morgan, J.E., Fogarty, N.M., Nielsen, S., \& Gilmour, A.R. (2006). Milk yield and milk composition from grazing primiparous nondairy crossbred ewes. Australian Journal of Agricultural Research, 57(4), 377-387.

Murawski, M., Schwarz, T., Jamieson, M., Ahmadi, B., \& Bartlewski, P.M. (2019). Echotextural characteristics of the mammary gland during early lactation in two breeds of sheep varying in milk yields. Animal Reproduction, 16(4), 853-858.

Naik, M.C., Krishnamoorthy, U., Nagaraja, R., \& Yathiraj, S. (2016). Lactation pattern in Mandya ewes and its influence on body weight gain in pre-weaning lambs. Indian Journal of Small Ruminants, 22(1), 22-27. :

Nava-García, A., Martínez-Rojero, R.D., Mastache-Lagunas, A.A., \& Ulloa-Arvizu, R. (2019). Curva de rendimiento y composición de leche en ovejas criollas de la Montaña de Guerrero, México. Ecosistemas y Recursos Agropecuarios, 6(17), 391-398.

Nezamidoust, M., Kominakis, A., \& Safari, A. (2013). Use of Wood's model to analyze the effects of milking methods on lactation curve in sheep. Small Ruminant Research, 113(1), 195-204.

Núñez-Domínguez, R., Ramírez-Valverde, R., Saavedra-Jiménez, L.A., \& García-Muñiz, J.G. (2016). La adaptabilidad de los recursos zoogenéticos Criollos, base para enfrentar los desafíos de la producción animal. Archivos de Zootecnia, 65(251): 461-468.

Ochoa-Cordero, M.A., Torres-Hernández, G., Mandeville, B.P., \& Díaz-Gómez, M.O. (2007). Effects of physiological and management factors on the milk composition of Rambouillet ewes. Agrociencia, 41(3), 263-270.

Ortega-Jiménez, E., Alexandre, G., Boval, M., Archimède, H., Mahieu, M., \& Xandé, A. (2005). Intake and milk production of suckling ewes reared at pasture in humid tropics according to the post-grazing management. Animal Research, 54(6), 459-469.

Peniche, G.I., Sarmiento, L., \& Santos, R. (2015). Estimation of milk production in hair ewes by two methods of measurement. Revista MVZ Córdoba, 20(2), 4629-4635. 
Peralta-Lailson, M., Trejo-González, A.A., Pedraza-Villagómez, P., Berruecos-Villalobos, J.M., \& Vásquez, C.G. (2005). Factors affecting milk yield and lactation curve fitting in the creole sheep of Chiapas-Mexico. Small Ruminant Research, 58(3), 265-273.

Pérez Corría, K., Fonseca Fuente, N., Vázquez Aldama, J., Rojas Gámez, N., Botello León, A., Zambrano Cuadro, N.G., Jinez Fernández, F.H., Ramírez de la Ribera, J.L., \& Chacón Marcheco, E. (2017). Respuesta productiva de la oveja Pelibuey en el período de lactancia alimentada con Leucaena leucocephala. Revista Electrónica de Veterinaria, 18(6), 1-8.

Portolano, B., Spatafora, F., Bono, G., Margiotta, S., Todaro, M., Ortoleva, V., \& Leto, G. (1996). Application of the Wood model to lactation curves of Comisana sheep. Small Ruminant Research, 24(1), 7-13.

Ramón-Ugalde, J.P., \& Sanginés-García, J.R. (2002). Response to ram effect in Pelibuey yearling ewes under grazing and supplemented conditions in a tropical environment. Técnica Pecuaria en México, 40(3), 309-317.

Robles-Jiménez, L.E., ángeles-Hernández, J.C., Palacios, C., Abecia, J.A., Naranjo, A., Osorio Avalos, J., \& Gonzalez-Ronquillo, M. (2020). Milk production of Lacaune sheep with different degrees of crossing with Manchega sheep in a commercial flock in Spain. Animals. doi:10.3390/ani10030520.

Snowder, G.D., \& Glimp, H.A. (1991). Influence of breed, number of suckling lambs, and stage of lactation on ewe milk production and lamb growth under range conditions. Journal of Animal Science, 69(3), 923-930.

Takma, Ç., Akbaş, Y., \& Taskin, T. (2009). Modeling lactation curves of Turkish Saanen and Bornova goats. Asian Journal of Animal and Veterinary Advances, 4(3), 122-129.

Tekel, N., Şireli, H.D., Karataş, A., Vural, M.E., Koncagül, S., \& Tutkun, M. (2019). Comparison of different lactation curve models to describe lactation curve in Awassi sheep raised in Turkey. Applied Ecology and Environmental Research, 17(6):1550715517.

Tsartsianidou, V., Kapsona, V.V., Sánchez-Molano, E., Basdagianni, Z., Carabaño, M.J., Chatziplis, D., Arsenos, G., Triantafyllidis, A., \& Banos, G. (2021). Understanding the seasonality of performance resilience to climate volatility in Mediterranean dairy sheep. Scientific Reports. https://doi.org/10.1038/s41598-021-81461-8

van der Linden, D.S., Kenyon, P.R., Blair, H.T., López-Villalobos, N., Jenkinson C.M.C., Peterson, S.W., \& Mackenzie, D.D.S. (2009). Effects of ewe size and nutrition on fetal mammary gland development and lactational performance of offspring at their first lactation. Journal of Animal Science, 87(12), 3944-3954.

Wood, P.D.P. (1967). Algebraic model of the lactation curve in cattle. Nature, 216, 164-165.

Zaragoza-Vera, C.V., Aguilar-Caballero, A.J., González-Garduño, R., Arjona-Jiménez, G., Zaragoza-Vera, M., Torres-Acosta, J.F.J., Medina-Reynés, J.U., \& Berumen-Alatorre, A.C. (2019). Variation in phenotypic resistance to gastrointestinal nematodes in hair sheep in the humid tropics of Mexico. Parasitology Research, 118(2), 567-573. 